\title{
ПЕРСПЕКТИВИ ВПРОВАДЖЕННЯ СТАНДАРТІВ ЯКОСТІ НАДАННЯ БЕЗОПЛАТНОЇ ВТОРИННОЇ ПРАВОВОЇ ДОПОМОГИ В ЦИВІЛЬНОМУ ТА КРИМІНАЛЬНОМУ ПРОЦЕСІ: НАЦІОНАЛЬНИЙ ТА ЄВРОПЕЙСЬКИЙ ДОСВІД
}

\author{
Ільків Н. В., Романцова С. В.
}

\section{ВСТУП}

Приєднанням 9 листопада 1995 р. до Ради Свропи Україна зобов'язалась дотримуватись обов'язків згідно зі Статутом Ради Свропи, зокрема, забезпечувати верховенство права та захист прав людини й основоположних свобод усіх осіб під іiі юрисдикцією, тим самим погодилась виконати таке спеціальне зобов'язання, визначене у висновку Парламентської Асамблеї № 190, як покращення доступу до правосуддя шляхом запровадження системи безоплатної правової допомоги відповідно до стандартів Ради Європи та практики Європейського суду з прав людини (п. 13.13 Резолюції Парламентської Асамблеї Ради Свропи «Про виконання обов'язків та зобов’язань Україною» від 5 жовтня 2005 р. № 1466).

Стартом для розвитку системи безоплатної правової допомоги (далі - БПД) стало ухвалення Верховною Радою України 2 червня 2011 р. Закону України «Про безоплатну правову допомогу» (далі - Закон № 3460-VI ) 1 , утворення 6 червня 2012 р. першої установи системи БПД - Координаційного центру 3 надання правової допомоги. А вже 31 січня 2013 р. в Україні розпочали роботу регіональні центри 3 надання безоплатної вторинної правової допомоги (далі - БВПП), на які покладалася функція надання БВПД підозрюваним і обвинуваченим у кримінальному провадженні, затриманим, заарештованим та засудженим. За даними офіційного сайту Міністерства юстиції України, натепер функціонують: 23 регіональні центри 3 надання БВПД; 84 місцевих центрів із надання БВПД; 428 бюро правової допомоги; 5 правових клубів "Pravokator"; 6760 адвокатів, залучених до надання БВПД; приблизно 1500 штатних юристів системи БПД. ${ }^{2}$

Можна стверджувати, що в нашій державі створена повноцінна система надання безоплатної правової допомоги. Але оскільки ключовим аспектом функціонування системи БПД є забезпечення ії якості, то система БПД продовжує розвиватися в напрямі забезпечення відповідності наданих

\footnotetext{
${ }^{1}$ URL: https://zakon.rada.gov.ua/laws/show/3460-17.

${ }^{2}$ URL: https://minjust.gov.ua/legal_aid.
} 
послуг міжнародним, зокрема європейським, стандартам надання правової допомоги як комплексу основних характеристик моделі гарантованого державою захисту. Натепер розроблені і схвалені Стандарти якості надання БВПД у цивільному, адміністративному процесах та представництва у кримінальному процесі (далі - Стандарти ЦАКП) ${ }^{3}$, Стандарти якості надання БВПД у кримінальному процесі (далі - Стандарти КП) ${ }^{4}$. Їх застосування має бути основою імплементації кращих практик надання юридичної допомоги, тому необхідне теоретичне обгрунтування правового й організаційного забезпечення надання БПД під час здійснення судочинства, реалізації права на захист прав та свобод громадян для виявлення суперечностей та прогалин у нормативно-правовому механізмі БПД, а також пошуку і наукового обгрунтування правових способів і засобів їх усунення. Отже, наукове обгрунтування забезпечення дії таких принципів БВПД, як iї доступність та якість надання, їхнього місця в механізмі забезпечення особі реального захисту прав, свобод та інтересів у результаті надання БПД $є$ актуальним напрямом наукових досліджень.

\section{1. Українська модель безоплатної вторинної правової допомоги}

Упровадження системи безоплатної правової допомоги в Україні $\epsilon$ гарантією реалізації конституційного права кожного на професійну правничу допомогу, що у випадках, передбачених законом, надається безоплатно (ст. 59 Конституції України), та важливим чинником побудови європейської моделі справедливого правосуддя. Після тривалого періоду в історії правової політики України, коли фіксувалися факти катувань та інших жорстоких видів поводження із затриманими, що надалі слугували підставою для засудження невинних осіб, у 2013 р. із запровадженням системи БПД було створено механізм реалізації громадянами правової можливості 3 отримання професійної правничої допомоги, зокрема й захисту підозрюваних $\mathrm{i}$ обвинувачених у вчиненні кримінальних правопорушень. Ця практика спрямована на забезпечення захисту прав i свобод людини i громадянина, їх відновлення в разі порушення. Позитивним $\epsilon$ законодавче закріплення численних правових послуг, які $\epsilon$ доступними в режимі БПД.

До переліку правових послуг у ст. 1 Закону № 3460-VI віднесено надання правової інформації, консультацій і роз'яснень із правових питань; складення

\footnotetext{
${ }^{3}$ Стандарти якості надання безоплатної вторинної правової допомоги у цивільному, адміністративному процесах та представництва у кримінальному процесі, затверджені наказом Міністерства юстиції України від 21 грудня 2017 р. № 4125/5. URL: https://zakon.rada.gov.ua/laws/show/z1554-17.

${ }^{4}$ Стандарти якості надання безоплатної вторинної правової допомоги у кримінальному процесі, затверджені наказом Міністерства юстиції України від 25 лютого 2014 p. № 386/5. URL: https://zakon.rada.gov.ua/ laws/show/z0337-14.
} 
заяв, скарг, процесуальних та інших документів правового характеру; здійснення представництва інтересів особи в судах, інших державних органах, органах місцевого самоврядування, перед іншими особами; забезпечення захисту особи від обвинувачення; надання особі допомоги в забезпеченні доступу особи до вторинної правової допомоги та медіації.

Залежно від виду правових послуг розрізняються такі види БПД, як безоплатна первинна і безоплатна вторинна правова допомога. Якщо БППД включає такі види правових послуг, як надання правової інформації, консультацій і роз'яснень із правових питань; складення заяв, скарг та інших документів правового характеру (крім документів процесуального характеру); надання консультацій, роз'яснень та підготовка проєктів договорів користування земельними ділянками для сільського населення - власників земельних ділянок; надання допомоги в забезпеченні доступу особи до вторинної правової допомоги та медіації (ч. 2 ст. 7 Закону № 3460-VI), то БВПД передбачає надання таких видів правових послуг, як: захист; здійснення представництва інтересів осіб, що мають право на безоплатну вторинну правову допомогу, у судах, інших державних органах, органах місцевого самоврядування, перед іншими особами; складення документів процесуального характеру (ч. 2 ст. 13 Закону № 3460-VI).

Тобто БППД розглядається як вид державної гарантії, що полягає в інформуванні особи про iii права і свободи, порядок їх реалізації, відновлення в разі їх порушення та порядок оскарження рішень, дій чи бездіяльності органів державної влади, органів місцевого самоврядування, посадових і службових осіб, а БВПД - як вид державної гарантії, що полягає у створенні рівних можливостей для доступу осіб до правосуддя (ст. ст. 7, 13 Закону № 3460-VI). Отже, БППД по суті охоплюється в основному компетенцією органів державної влади й органів місцевого самоврядування надавати послуги, що $\epsilon$ змістом їхньої діяльності, а вторинна передбачається для окремо визначених, переважно вразливих, верств населення із забезпечення можливості захисту порушеного права в суді.

Як слушно зазначається в науковій літературі на основі аналізу поділу БПД, законодавець диференціює поняття «доступ до права» (англ. access to law, фр. acces au droit) та «доступ до правосуддя» (англ. access to justice, фр. acces au justice) як правові категорії, що є різними як за своєю формою та змістом, так і за способом реалізації.

\footnotetext{
5 Козьяков I., Говоруха О. Актуальні питання реалізації принципів надання безоплатної правової допомоги. Науковий часопис Наџіональної академії прокуратури Украӥни. 2018. № 1 (17). С. $107-116$. URL: http://www.chasopysnapu.gp.gov.ua/ua/pdf/1-2018/koziakov_govoruha.pdf.
} 
Відповідно законодавчо визначене відмінне коло суб'єктів надання цих видів БПД. До суб'єктів надання БВПД в Україні віднесені: центри з надання БВПД, які утворюються рішенням Міністерства юстиції України (далі центри); і адвокати, включені до Реєстру адвокатів, які надають БВПД.

Серед послуг БВПД, що надаються центром, - забезпечення представництва інтересів осіб у судах, інших державних органах, органах місцевого самоврядування, перед іншими особами на підставі довіреності, виданої особою, яка звернулася за наданням БВПД, а також надання інших видів правових послуг БВПД таким особам; забезпечення складання документів процесуального характеру та здійснення представництва інтересів особи, засудженої до покарання у вигляді позбавлення волі, тримання в дисциплінарному батальйоні військовослужбовців або обмеження волі, за зверненням такої особи або за ухвалою суду в судах, інших органах державної влади, органах місцевого самоврядування, перед іншими особами, залучення у встановленому порядку перекладача (сурдоперекладача); уповноваження працівників місцевих центрів для здійснення представництва інтересів осіб у суді, у спорах, що виникають із трудових відносин, спорах щодо захисту соціальних прав, щодо виборів та референдумів, у малозначних спорах, а також щодо представництва малолітніх чи неповнолітніх осіб та осіб, які визнані судом недієздатними чи дієздатність яких обмежена, або для складення документів процесуального характеру (пп. пп. 11, 12, 20 п. 13 Положення про центри з надання БВПД (далі - Положення) $)^{6}$ ).

Але варто відзначити, що центри, що забезпечують надання послуг, які охоплюються змістом БВПД, можуть надавати і БППД (п. 5 ч. 1 ст. 9 Закону № 3460-VI, п. 7 Положення). Так, місцеві центри БВПД, відповідно до п. 13 Положення, поширюють інформацію у сфері захисту прав, свобод i законних інтересів громадян, надання безоплатної правової допомоги; проводять тематичні семінари, лекції; для визначених категорій громадян, зокрема пенсіонерів, осіб з інвалідністю, учасників антитерористичної операції, молоді, громадських активістів, учителів та педагогічних працівників, медичних працівників, інших вразливих суспільних груп із метою підвищення правової свідомості, культури й освіченості населення, запобігання кримінальній протиправності; здійснюють особистий прийом і облік осіб, які звертаються до місцевого центру для отримання БПД, роз'яснюють положення законодавства у сфері БПД і порядок отримання такої допомоги; розглядають звернення осіб про надання БППД протягом

\footnotetext{
${ }^{6}$ Положення про центри 3 надання безоплатної вторинної правової допомоги, затверджене наказом Міністерства юстиції України від 2 липня 2012 р. № 967/5, у редакції наказу Міністерства юстиції України від 24 травня 2016 р. № 1487/5. URL: https://zakon.rada.gov.ua/laws/show/z1091-12.
} 
десяти днів із дня надходження зазначеного звернення; надають правову інформацію, консультації і роз'яснення із правових питань; забезпечують складення заяв, скарг та інших документів правового характеру; забезпечують відвідування осіб, зокрема одиноких, похилого віку, 3 обмеженими фізичними можливостями, за місцем їх перебування, а також осіб, які постраждали від домашнього насильства або насильства за ознакою статі, на базі загальних та спеціальних служб підтримки постраждалих осіб із метою надання зазначеним особам БПД; забезпечують надання доступу до електронних сервісів Міністерства юстиції України; надають консультації, роз'яснюють правила пошуку та порядок отримання відомостей із зазначених сервісів; надають органам місцевого самоврядування консультаційно-методичну допомогу 3 питань утворення спеціалізованих установ, які надають БППД, залучення до іiі надання юридичних осіб приватного права та фізичних осіб; взаємодіють з іншими суб'єктами, що здійснюють заходи у сфері запобігання та протидії домашньому насильству тощо. Усі ці види послуг охоплюються змістом БППД.

Необхідно зауважити, що у ст. 17 Закону «Про БПД» послугам БППД, що надаються центрами, не приділена належна увага. Однак, виходячи з того, що центр лише для здійснення представництва інтересів осіб, які мають право на БВПД, у суді у спорах, що виникають із трудових відносин, спорах щодо захисту соціальних прав, щодо виборів та референдумів, у малозначних спорах, а також щодо представництва малолітніх чи неповнолітніх осіб та осіб, які визнані судом недієздатними чи дієздатність яких обмежена, або для складання документів процесуального характеру уповноважує свого працівника (ч. 4 ст. 21 Закону № 3460-VI), а в усіх інших випадках по суті призначає адвоката, який надає БВПД на постійній основі за контрактом або укладає договір з адвокатом, включеним до Реєстру адвокатів, які надають БВПД, то на законодавчому рівні варто ширше закріпити перелік послуг із надання БППД центрами.

Визначення центрів як суб'єктів надання БППД свідчить про надання можливості отримання БППД, в основному правових консультацій та складання непроцесуальних документів, також у кримінальному провадженні, причому на всіх етапах. Особа, затримана в межах кримінального провадження або провадження у справах про адміністративні правопорушення, має право на отримання БПД із моменту затримання. Хоча кримінально-процесуальне законодавство не встановлює у прямій формі можливість отримання БПД із моменту затримання і до проведення першого допиту, але це випливає із системного тлумачення низки правових норм. Забезпечення раннього доступу до правової допомоги $\epsilon$ пріоритетом для системи БПД в Україні. 
Таким шляхом іде практика Європейського суду з прав людини (далі ЄСПЛ), якщо широко трактувати основну мету, яка визначена у ст. 6 Конвенції про захист прав людини та основоположних свобод (далі ЄКПЛ), у контексті кримінального провадження, зазначено, що вона полягає не тільки в забезпеченні справедливого розгляду компетентним «судом» визначення обгрунтованості будь-якого «кримінального обвинувачення», але може застосовуватись до досудового провадження, тобто передбачає надання доступу до адвоката, зазвичай із першого допиту підозрюваного поліцією, якщо $з$ огляду на конкретні обставини кожної справи не буде встановлено, що існують вагомі причини обмежувати таке право. Отже, п. 3 ст. 6 може бути застосовною і коли справу ще не передано до суду, якщо справедливість судового розгляду можна було б поставити під серйозний сумнів, якщо не було дотримано її положень від самого початку ${ }^{7}$.

Забезпечення раннього доступу осіб, які вважаються підозрюваними та до яких застосовано тимчасовий запобіжний захід - затримання, до БПД здійснюється центрами відповідно до Порядку інформування центрів із надання БВПД про випадки затримання, адміністративного арешту або застосування запобіжного заходу у вигляді тримання під вартою․ Однак відсутність чіткої норми у Кримінальному процесуальному кодексі (далі КПК) України призводить до того, що правоохоронні органи, які здійснюють затримання, подекуди не сповіщають про нього центри та намагаються уникнути обов'язкового залучення адвоката. Тому для забезпечення в Україні дієвого раннього доступу до БПД треба забезпечити механізм узгоджених дій суб'єктів кримінальної юстиції та суб'єктів надання БПД через використання інформації електронних баз даних (реєстри). Важливо передбачити цей механізм у ст. 12 КПК України «Забезпечення права на свободу та особисту недоторканність», доповнити іiі так: «Про затримання особи, взяття iї під варту або обмеження у праві на вільне пересування в інший спосіб, а також про ії місцеперебування має бути негайно повідомлено центри 3 надання БВПД через механізми електронної взаємодії», а у ст. 42 КПК України поряд з іншими правами підозрюваного закріпити додатково таке їхне право: «у разі затримання або застосування запобіжного заходу у вигляді тримання під вартою - на негайне повідомлення центрів із надання БВПД».

\footnotetext{
7 Рішення ЄСПЛ у справі «Імбріошіа проти Швейцарії» (“Imbrioscia v. Switzerland”) від 24 листопада 1993 р., п. 36.

8 Порядок інформування центрів із надання безоплатної вторинної правової допомоги про випадки затримання, адміністративного арешту або застосування запобіжного заходу у вигляді тримання під вартою : постанова Кабінету Міністрів України від 28 грудня 2011 р. № 1363, у редакції від 11 березня 2015 p. № 110, із змінами. URL: https://zakon.rada.gov.ua/laws/show/1363-2011-п.
} 


\section{2. Умови надання безоплатної вторинної правової допомоги}

Українська система правової допомоги сприяє широкому доступу до правосуддя та забезпечує ефективніший захист прав людини, передбачає широке коло осіб, які можуть отримати БВПД. Так, згідно з Конституцією України та Законом № 3460-VI, право на БППД мають усі особи, які перебувають під юрисдикцією України. Однак право на БВПД, на відміну від первинної, мають лише окремі категорії осіб, визначені у ст. 14 Закону № 3460-VI. Власне в такому законодавчому закріпленні дістав відображення європейський підхід, який полягає у врахуванні двох факторів-умов для віднесення осіб до тих, які мають право на БПД: поперше, у такої особи немає достатніх коштів для оплати послуг захисника (що встановлюється так званим «тестом на нужденність»), тобто фінансового критерію, по-друге, надання безоплатної правової допомоги вимагається інтересами правосуддя (що встановлюється так званим «тестом по суті»), тобто юридичного критерію. Ці дві умови викладені як у пп. «с» п. 3 ст. 6 ЄКПЛ (щодо обвинуваченого у вчиненні кримінального правопорушення), так і у ст. 14 Міжнародного пакту про громадянські і політичні права. Щоб скористатися правовою допомогою, необхідно відповідати обом критеріям, фінансовому і юридичному, якщо тільки національним законодавством не встановлені більш високі стандарти ${ }^{9}$. Це означає, що, відповідно до європейського законодавства та практики ЄСПЛ, БПД - це не право, гарантоване кожному, хто бере участь у кримінальному провадженні, $\mathrm{i}$ держави зобов'язані надавати цю допомогу не всім, а лише тим, кому бракує коштів, щоб найняти адвоката, і де в інтересах правосуддя в конкретному типі справи чи провадження потрібне надання правової допомоги.

Надання БВПД в Україні здійснюється з урахуванням двох критеріїв фінансового критерію та належності до тих категорій осіб, для яких законодавчо закріплено право на БПД. Але законодавство України щодо надання БВПД $є$ демократичнішим від європейського законодавства, не вимагає сукупності критеріїв для отримання БВПД.

Перелік категорій осіб, які є суб'єктами права на БВПД, досить широкий, складений $з$ урахуванням сфер, дотримання прав у яких потребують реагування з боку держави. Українська система БПД передбачає широке коло осіб, які можуть отримати БВПД у кримінальному провадженні, у разі адміністративного затримання й арешту, а також для відновлення і захисту своїх порушених прав, чим сприяє широкому доступу до правосуддя.

\footnotetext{
9 Оцінювання системи безоплатної вторинної правової допомоги в Україні у світлі стандартів і передового досвіду Ради Європи : звіт у межах проєкту Ради Європи «Подальша підтримка реформи кримінальної юстиції в Україні». 2016. С. 34. URL: https://rm.coe.int/16806ff4a9.
} 
Перелік суб'єктів права на БВПД і надалі розширюється. Зокрема, у зв'язку з активізацією земельної реформи Закон доповнено новою категорією суб'єктів - громадяни України - власники земельних ділянок, які проживають у сільській місцевості. Отже, суб'єктами права на БВПД переважно є соціально незахищені категорії, які не мають можливості самостійно оплатити послуги, а отже, не $є$ клієнтами «платних адвокатів». Однак особи, які мають право на БВПД, можуть скористатися лише визначеними правовими послугами. Варто зазначити, що залежно від того, до якої категорії належить особа, визначається перелік послуг із БВПД, час їх надання та максимальна кількість.

Закріплення переліку суб'єктів, які мають право на БВПД, спрямоване на реалізацію такого важливого принципу демократичної держави, як право на доступ до правосуддя. Оскільки обов'язком держави є забезпечення особі реального, а не формального доступу до суду в результаті надання правової допомоги ${ }^{10}$, то проведемо дослідження стану фактичного забезпечення дотримання такого принципу цієї допомоги, як їі доступність.

Аналіз кількості звернень до центрів свідчить, що найбільш поширена категорія осіб, які потребують БПД, - це малозабезпечені громадяни ${ }^{11}$. Згідно із процедурою, установленою у ст. 18 Закону, звернення про надання одного 3 видів правових послуг подаються особами, які досягли повноліття, до Центру 3 надання БВПД або до територіального органу юстиції за місцем фактичного проживання таких осіб незалежно від реєстрації місця проживання чи місця перебування особи. Якщо особа належить до однієї з таких категорій, то Центр ухвалює рішення про надання БВПД, якщо ж установлює відсутність підстав для отримання БВПД, - про відмову в наданні БВПД.

Нормативне закріплення цих положень 3 огляду на принцип правової визначеності начебто не викликає жодних сумнівів щодо реалізації задекларованих гарантій. Водночас положення ч. 4 ст. 18 Закону № 3460-VI, відповідно до якого разом зі зверненням про надання БВПД особа повинна подати документи, що підтверджують їі належність до однієї із вразливих категорій осіб.

Відповідає такий порядок і європейській практиці. Так, ССПЛ установив, що тягар доказування браку коштів треба покладати на особу, яка звернулася по допомогу ${ }^{12}$, а брак фінансових коштів не варто встановлювати

\footnotetext{
${ }^{10}$ Ісакова В. Право на правову допомогу як елемент принципу доступності правосуддя. Форум права. 2012. № 4. C. 404-410. URL: http://nbuv.gov.ua/UJRN/FPindex.htm.

11 Сірош Д. Фінансування витрат на безоплатну правову допомогу в судочинстві України. Наукові записки Інституту законодавства Верховної Ради Украӥни. 2014. № 2. C. 102-106. URL: http://nbuv.gov.ua/ UJRN/Nzizvru.

${ }^{12}$ Рішення ССПЛ у справі «Круассан проти Німеччини» (“Croissant v. Germany”) від 25 вересня 1992 р., п. 37.
} 
«поза всяким сумнівом», обвинуваченого треба вважати таким, що має право на правову допомогу за фінансовим критерієм, якщо існують «деякі ознаки» браку коштів і «немає чітких ознак протилежного» ${ }^{13}$.

Тобто йдеться про отримання та самостійну підготовку низки документів, які вимагаються центрами для підтвердження статусу особи як такої, що має право на отримання БВПД. Однак на практиці це зумовлює в багатьох осіб, які звертаються за отриманням БПД, виникнення досить багатьох труднощів, що впливає на доступ до самої правової допомоги ${ }^{14}$.

Наприклад, якщо середньомісячний дохід особи не перевищує двох розмірів прожиткового мінімуму, розрахованого та затвердженого відповідно до закону для осіб, які належать до основних соціальних i демографічних груп населення, а також особи з інвалідністю, які отримують пенсію або допомогу, що призначається замість пенсії, у розмірі, що не перевищує двох прожиткових мінімумів для непрацездатних осіб (п. 1 ч. 1 ст. 14 Закону № 3460-VI), то особа має право на отримання БВПД. Проте для цього потрібно подати до центру комплект із восьми окремих документів, як-от: паспорт або інший документ, що посвідчує особу; реєстраційний номер облікової картки платника податків; довідка про доходи за останні 6 місяців; довідка про перебування на обліку в центрі зайнятості та проведені виплати - у разі звернення до місцевого центру осіб, зареєстрованих у встановленому порядку як безробітні (за наявності); довідка про подану декларацію про майновий стан і доходи (про сплату податку на доходи фізичних осіб та про відсутність податкових зобов'язань 3 такого податку), видана відповідним центром обслуговування платників Державної фіскальної служби (далі - ДФС); відомості з Державного реєстру фізичних осіб - платників податків ДФС, зокрема щодо сум виплачених доходів та утриманих податків; довідка про інформацію, що міститься в реєстрі застрахованих осіб Державного реєстру загальнообов'язкового державного соціального страхування, зокрема щодо одержаного доходу та/або виду та розміру призначеної пенсії за останні 6 місяців.

В інформаційному аспекті варто зауважити, що зазначений перелік документів особа, яка потребує правової допомоги, не знайде в Законі, оскільки його наведено в Методичних рекомендаціях щодо організації надання БПД місцевими центрами 3 надання БВПД ${ }^{15}$, про які відомо не кожній особі, адже Закон не містить посилання на них. I хоча зазначений акт

\footnotetext{
${ }^{13}$ Рішення ССПЛ у справі «Пакеллі проти Німеччини» (“Pakelli v. Germany”) від 25 квітня 1983 р.

14 Козьяков I., Говоруха О. Актуальні питання реалізації принципів надання безоплатної правової допомоги. Науковий часопис Національної академії прокуратури Украӥни. 2018. № 1 (17). С. $107-116$.

15 Про затвердження Методичних рекомендацій щодо організації надання безоплатної правової допомоги місцевими центрами 3 надання безоплатної вторинної правової допомоги : наказ Координаційного центру 3 надання правової допомоги від 19 липня 2019 р. № 60. URL: https://zakon.rada.gov.ua/rada/show/v0060419-19.
} 
є організаційно-розпорядчим документом, що розроблений та рекомендований для використання суто працівниками місцевих центрів під час прийому осіб, які звертаються за отриманням правової допомоги, що прямо зазначається в ньому, наголошується, що він «не є нормативно-правовим актом та не встановлює обов'язкових норм (правил поведінки) для осіб, які звертаються за правовою допомогою до місцевих центрів», однак системний аналіз положень, викладених у рекомендаціях, засвідчує наявність низки прогалин в окремих аспектах регулювання цього питання.

Хоча в п. 6 Методичних рекомендацій закріплено категоричне правило, яким установлено заборону відмови у прийнятті заяви про надання БВПД через відсутність повного комплекту документів, що підтверджують належність особи до однієї із вразливих категорій осіб, визначених ст. 14 Закону, але подальший алгоритм дій працівника центру в разі прийняття заяви про надання БВПД свідчить про неминучу необхідність для особи подати такі документи. Зокрема, працівник Центру після сканування документів видає особі талон про прийняття заяви про надання БВПД. У талоні, зокрема, зазначається перелік отриманих документів, а також тих, які необхідно подати додатково. Під час видання талона клієнту / представнику клієнта роз'яснюється, що рішення про надання БВПД або відмову в ㄲï наданні ухвалюється місцевим центром протягом десяти днів із дня отримання заяви та всіх необхідних документів, про що його буде поінформовано додатково після прийняття всіх необхідних документів, що підтверджують належність клієнта до однієї із вразливих категорій осіб, визначених Законом. I лише після прийняття всіх необхідних документів працівник центру перевіряє належність особи до відповідної категорії.

Кінцевий результат цієї перевірки визначено в п. 10 рекомендацій, згідно 3 яким, якщо за результатами перевірки встановлено, що особа належить до вразливих категорій осіб та подала необхідні документи, що підтверджують таку належність, працівник готує проєкт наказу місцевого центру про надання БВПД, якщо ж установлено, що особа не належить, - про відмову в наданні БВПД, де зазначаються підстави для такої відмови.

Отже, відмовити у прийнятті звернення особи у зв'язку з неподанням усіх необхідних документів забороняється, однак у такому разі неможливо визначити приналежність особи до категорії, отже, на цій підставі їй буде відмовлено в наданні допомоги. Тож постає запитання щодо доцільності прийняття заяви без необхідних додаткових документів, адже ухвалення рішення про надання БВПД визначається від дня отримання заяви та всіх необхідних документів (десять днів). Застосування ж такої підстави для відмови в наданні БВПД, як неприналежність особи до жодної з категорій осіб, передбачених Законом № 3460-VI (п. 1 ст. 20), передбачає дослідження документів, на основі яких цей факт можна встановити. 
Отже, перелік підстав для відмови в наданні БВПД, визначений ст. 20 Закону, треба розширити, зафіксувати в п. 2 поряд із такою підставою, як «особа подала неправдиві відомості або фальшиві документи 3 метою віднесення іiі до однієї категорій осіб, які мають право на БВПД», також і неподання всіх необхідних документів.

Хоча практика ЄСПЛ іде шляхом віднесення визначення правил щодо фінансового критерію, зокрема фінансового порога і методів перевірки того, чи має особа право на отримання правової допомоги, до розсуду відповідних держав, але наголошується, що критерії та методика відбору справ, за якими надається право на правову допомогу, повинні бути чіткими, система має забезпечувати вагомі процедурні гарантії проти свавілля під час фінансової оцінки для вирішення питання, чи має особа право на правову допомогу ${ }^{16}$.

\section{3. Стандарти якості надання безоплатної вторинної}

\section{правової допомоги як елемент права на справедливий суд}

Ключовим аспектом надання БВПД є забезпечення іiі якості. Принцип забезпечення якості БПД на законодавчому рівні визначено серед принципів державної політики у сфері надання БПД (ст. 5 Закону № 3460-VI).

Право на якісну БПД $є$ елементом реалізації такого важливого принципу демократичної держави, як право на справедливий суд. Як гарантію права на справедливий суд розглядає його і ЄСПЛ. Так, у рішенні ЄСПЛ від 12 червня 2008 р. у справі «Яременко проти України»" ${ }^{17}$ порушення пп. «с» п. 3 ст. 6 СКПЛ було констатоване у зв'язку з тим, що у справі про вбивство водія таксі, яка порушена за фактом завдання тяжких тілесних ушкоджень, унаслідок яких сталася смерть потерпілого, рішення про визнання заявника винним у вчиненні злочину грунтувалося головним чином на його зізнанні, яке слідчі здобули за відсутності захисника. Суд у п. 90 рішення вказує ще на одну обставину - «кожен із двох інших захисників, які представляли заявника, бачив його лише один раз і тільки під час допиту, і те, що до допиту ніхто 3 них із заявником не бачився, найімовірніше, свідчить про символічний характер їхніх послуг». Фактично висновок про неналежну якість наданої правової допомоги послужив підставою для рішення Суду про порушення права на справедливий суд.

Виходячи з того, що ознакою високої чи низької якості є відповідність або невідповідність передбаченим вимогам ${ }^{18}$, якість надання тих чи інших

\footnotetext{
${ }^{16}$ Рішення ССПЛ у справі «Сантамброджо проти Італії» (“Santambrogio v. Italy”) від 21 вересня 2004 р., п. п. 54, 55.

${ }^{17}$ Рішення ССПЛ у справі «Яременко проти України» від 12 червня 2008 p. URL: https://zakon.rada.gov.ua/ laws/show/974-405.

${ }^{18}$ Блащук Т. Поняття якості у праві України. Підприємнищтво, господарство і право. 2011. № 3 (183). C. 11-13.
} 
послуг (юридичних також) визначається їхньою відповідністю за формою та змістом певним вимогам.

Основні правові вимоги у сфері БПП закріплені у ст. 26 Закону № 3460-VI як обов'язки адвоката або працівника Центру під час надання БВПД. Однак вони мають дуже загальний характер. Ці вимоги конкретизовані у Стандартах КП та Стандартах ЦАКП. Ці Стандарти охоплюють усі стадії провадження. Однак не менш важлива доступність якісної правової допомоги після ухвалення вироку та під час виконання покарання. Але в законодавстві України акцентується увага лише на здійсненні «захисту у кримінальному провадженні під час досудового розслідування та судового провадження» (п. 3 ч. 1 ст. 17, п. 1 ч. 1 ст. 25 Закону). Деякою мірою це питання врегульовано в Порядку надання БПД працівниками місцевих центрів із надання БВПД ${ }^{19}$, однак для ефективності реалізації такого положення воно має бути закріплене на рівні Закону, відображене у Стандартах.

Стандарти, які грунтуються на принципах верховенства права, законності, незалежності адвокатської діяльності, конфіденційності, уникнення конфлікту інтересів, пріоритету інтересів клієнта, компетентності та добросовісності у виконанні адвокатом своїх професійних обов'язків, являють собою концентровані в одному документі й адаптовані до конкретних процесуальних ситуацій алгоритми дій захисника, які випливають із вимог відповідного законодавства та Правил адвокатської етики. Стандарти схожі на контрольний перелік дій, що адвокати, які надають БВПД, зобов'язані виконувати на кожному етапі провадження. Стандарти можуть слугувати особі, яка звернулась по допомогу, орієнтиром для оцінки якості, наданої їй БПД.

Значення Стандартів для держави, що виступає замовником та платником послуг із надання БПД, полягає в тому, що вони забезпечують виконання такого «державного замовлення» на належному рівні. За умови дотримання адвокатами Стандартів забезпечується захист особи від неякісної правової допомоги, ефективне обстоювання iї прав та законних інтересів, забезпечення рівності такої особи з іншими учасниками процесу.

Критерії оцінки якості надання БПП уже давно діють у більшості країн Європейського Союзу. Загальний підхід ЄСПЛ зумовлюється переконанням, що одержувач безоплатної правової допомоги обмежений у можливостях самостійно контролювати якість і ефективність роботи адвоката в порівнянні з особою, що самостійно оплачує правову допомогу. Із цієї причини ЄСПЛ вимагає від держав ужиття заходів із забезпечення належної роботи призначених адвокатів.

\footnotetext{
${ }^{19}$ Порядок надання безоплатної правової допомоги працівниками місцевих центрів із надання безоплатної вторинної правової допомоги : наказ Координаційного центру 3 надання правової допомоги від 28 січня 2019 р. № 2. URL: https://zakon.rada.gov.ua/rada/show/v0002419-19.
} 
Однак проблематичним є встановлення ступеня дотримання Стандартів. Оцінювання якості надання БВПД здійснюється відповідно до Стандартів комісіями, утвореними для цього радами адвокатів регіонів, за поданням відповідних центрів.

Світова спільнота вже давно користується Peer Review у сфері надання правової допомоги (зокрема, БПД) як формою експертної оцінки, яка проводиться незалежними досвідченими експертами, що практикують оцінку якості роботи інших професіоналів на основі певних критеріїв, визначених і узгоджених у професійній спільноті рівнів ефективності. Важливо у здійсненні такої фахової оцінки адвокатських справ забезпечити iii незалежність через доручення науковим установам чи незалежним громадським об'єднанням, з анонімністю вихідних даних у справі.

Вивчення досвіду закордонних країн дозволяє вести мову про відсутність одноманітності в системах оцінки якості БПД. Кожного разу система оцінки розробляється окремо, на основі конкретних цілей і завдань тієї програми, реалізацію якої планують оцінювати. Тож, неможливо цілком запозичувати і використовувати готові алгоритми та шаблони для оцінки послуг у системі БПД. Але ефективні системи оцінки відповідають зазвичай тим самим основним принципам.

Як слушно зазначає Р. Сміт, ключові складники якості надання правової допомоги такі: 1) встановлені правила щодо обсягу й доступності послуг правової допомоги, які повинні бути перевіреними правилами, з вивченням того, наскільки схема надання послуг правової допомоги відповідає мінімальним вимогам міжнародних угод і більш широким вимогам сучасних практичних методів їх застосування; 2) етика, яка стосується не лише загальних питань, як-от боротьба з корупцією, але також передбачає повагу до першочергового інтересу клієнта; 3) технічна компетентність, тобто рівень кваліфікованості фахівця, який надає правову допомогу ${ }^{20}$.

\section{ВИСНОВКИ}

Система БПД є важливим елементом побудови прозорої й ефективної системи правосуддя, що продовжує розвиватися в напрямі забезпечення відповідності наданих послуг міжнародним, зокрема європейським, стандартам надання правової допомоги як комплексу основних характеристик моделі гарантованого державою захисту.

Закріплення та постійне розширення переліку суб'єктів, які мають право на БВПД, спрямоване на реалізацію такого важливого принципу демократичної держави, як право на доступ до правосуддя.

\footnotetext{
${ }^{20}$ Сміт Р. Міжнародні стандарти надання правової допомоги : порівняльний аналіз. URL: http: //yur-gazeta. com/publications/practice/inshe/-mizhnarodni-standarti-nadannya-pravovoyi-dopomogi-porivnyalniy-analiz.html.
} 
Доцільно для забезпечення в Україні дієвого раннього доступу до БПД забезпечити механізм узгоджених дій суб'єктів кримінальної юстиції та суб'єктів надання БПД через використання механізмів електронної взаємодії. Із цією метою пропонується внести зміни до ст. 12 КПК України, доповнити ії нормою такого змісту: «Про затримання особи, взяття іiі під варту або обмеження у праві на вільне пересування в інший спосіб, а також про ii місцеперебування має бути негайно повідомлено центри 3 надання БВПД через механізми електронної взаємодії», а у ст. 42 КПК України поряд з іншими правами підозрюваного закріпити додатково їхнє право «у разі затримання або застосування запобіжного заходу у вигляді тримання під вартою - на негайне повідомлення центрів з надання БВПД».

Стандарти якості надання БПД і відповідні механізми моніторингу їх дотримання $є$ найбільш важливими заходами забезпечення якості БПД. Встановлено проблематичність визначення ступеня дотримання Стандартів якості надання БВПД. Контроль за дотриманням Стандартів якості дозволить гарантувати особам, які звернулися по допомогу, якість послуг, а адвокатам/юристам системи БПД забезпечить захист від необгрунтованих претензій. Важливо в разі здійснення Peer Review як незалежної фахової оцінки адвокатських справ забезпечити іiі незалежність через доручення науковим установам чи незалежним громадським об'єднанням, 3 анонімністю вихідних даних у справі.

У побудові системи оцінки якості БПД необхідно орієнтуватися не тільки на суто юридичну роботу юристів (адвокатів), також варто враховувати особливості правового статусу одержувачів цієї допомоги, а також різні організаційні аспекти, що впливають на доступ до такої допомоги та ії якість.

\section{АНОТАЦІЯ}

Здійснено дослідження проблеми доступності в отриманні безоплатної правової допомоги в Україні як важливого принципу державної політики. Окреслено нормативно-правові засади застосування інституту безоплатної правової допомоги. Констатовано, що в контексті виконання міжнародних зобов'язань Україна зробила істотні кроки для визначення стандартів якості надання безоплатної правової допомоги в цивільному, адміністративному та кримінальному процесі. Визначено, що Стандарти якості надання безоплатної правової допомоги і відповідні механізми моніторингу ïx дотримання $\epsilon$ найбільш важливими заходами забезпечення якості безоплатної правової допомоги. На основі проведеного дослідження запропоновано шляхи вдосконалення механізму реалізації права особи на якісну безоплатну вторинну правову допомогу. Зроблено висновок, що в побудові системи оцінки якості безоплатної правової допомоги необхідно 
враховувати як роботу юристів/адвокатів, так і особливості правового статусу одержувачів цієї допомоги, а також різні організаційні аспекти, що впливають на доступ до такої допомоги та ії якість.

\section{ЛІТЕРАТУРА}

1. Про безоплатну правову допомогу : Закон України від 2 червня 2011 p. № 3460-VI. URL: https://zakon.rada.gov.ua/laws/show/3460-17.

2. Стандарти якості надання безоплатної вторинної правової допомоги в цивільному, адміністративному процесах та представництва у кримінальному процесі, затверджені наказом Міністерства юстиції України від 21 грудня 2017 р. № 4125/5. URL: https://zakon.rada.gov.ua/laws/show/z1554-17.

3. Стандарти якості надання безоплатної вторинної правової допомоги у кримінальному процесі, затверджені наказом Міністерства юстиції України від 25 лютого 2014 р. № 386/5. URL: https://zakon.rada.gov.ua/ laws/show/z0337-14.

4. Козьяков I., Говоруха О. Актуальні питання реалізації принципів надання безоплатної правової допомоги. Науковий часопис Національної академії прокуратури Украӥни. 2018. № 1 (17). С. 107-116. URL: http://www.chasopysnapu.gp.gov.ua/ua/pdf/1-2018/koziakov_govoruha.pdf.

5. Положення про центри 3 надання безоплатної вторинної правової допомоги, затверджено наказом Міністерства юстиції України від 2 липня 2012 № 967/5, у редакції наказу Міністерства юстиції України від 24 травня 2016 p. № 1487/5. URL: https://zakon.rada.gov.ua/laws/show/z1091-12.

6. Оцінювання системи безоплатної вторинної правової допомоги в Україні у світлі стандартів і передового досвіду Ради Свропи : звіт у межах проєкту Ради Європи «Подальша підтримка реформи кримінальної юстиції в Україні». 2016. С. 34. URL: https://rm.coe.int/16806ff4a9.

7. Ісакова B. Право на правову допомогу як елемент принципу доступності правосуддя. Форум права. 2012. № 4. С. 404-410. URL: http://nbuv.gov.ua/UJRN/FP_index.htm_2012_4_67.

8. Сірош Д. Фінансування витрат на безоплатну правову допомогу в судочинстві України. Наукові записки Інституту законодавства Верховної Ради України. 2014. № 2. С. 102-106.

9. Про затвердження Методичних рекомендацій щодо організації надання безоплатної правової допомоги місцевими центрами 3 надання безоплатної вторинної правової допомоги : наказ Координаційного центру з надання правової допомоги від 19 липня 2019 р. № 60. URL: https://zakon.rada.gov.ua/rada/show/v0060419-19.

10. Блащук Т. Поняття якості у праві України. Підприємництвво, господарство і право. 2011. № 3 (183). С. 11-13. 
11. Порядок надання безоплатної правової допомоги працівниками місцевих центрів з надання безоплатної вторинної правової допомоги: наказ Координаційного центру з надання правової допомоги від 28 січня 2019 р. № 2. URL: https://zakon.rada.gov.ua/rada/show/v0002419-19.

12. Демченко О. Практичні аспекти застосування стандартів якості надання безоплатної правової допомоги в Україні в порівнянні з іншими країнами ЄС. Адаптація правової системи України до права Європейського Союзу : теоретичні та практичні аспекти : матеріали II Всеукраїнської науково-практичної конференції, м. Полтава, 23 листопада 2017 р. : у 2-х ч. Полтава : Россава, 2017. Ч. 1. С. 210-212.

13. Сміт Р. Міжнародні стандарти надання правової допомоги : порівняльний аналіз. URL: http://yur-gazeta.com/publications/practice/inshe/mizhnarodni- standarti-nadannya-pravovoyi-dopomogi-porivnyalniy-analiz.html.

Information about authors: Ilkiv N. V.,

Candidate of Law Sciences, Associate Professor, Associate Professor at the Department of Economic-Legal Disciplines

Lviv State University of Internal Affairs 26, Horodotska str., Lviv, 79007, Ukraine

Romantsova S. V., Candidate of Law Sciences, Senior Lecturer at the Department of Criminal-Legal Disciplines Lviv State University of Internal Affairs 26, Horodotska str., Lviv, 79007, Ukraine 